\title{
Anatomical root variations in response to water deficit: wild and domesticated common bean (Phaseolus vulgaris L.)
}

\author{
Cecilia B. Peña-Valdivia ${ }^{1 *}$, Adriana B. Sánchez-Urdaneta², Joel Meza Rangel ${ }^{3}$, Juana Juárez Muñoz ${ }^{3}$, \\ Rodolfo García-Nava ${ }^{1}$ and Raquel Celis Velázquez ${ }^{1}$ \\ ${ }^{1}$ Botánica, Colegio de Postgraduados. Km 35.5 Carretera México-Texcoco, Montecillo, México, 56230. México. \\ 2 Facultad de Agronomía, Universidad del Zulia, Av. Ziruma, Maracaibo, Venezuela. \\ 3 Instituto de Ciencias Agropecuarias de la Universidad Autónoma del Estado de Hidalgo. Rancho Universitario s/n, Exhacienda de Aquetzalpa. Tulancingo, Hgo.
}

\begin{abstract}
Root anatomical responses to water deficit are diverse and regulation of water uptake strongly depends on plant anatomy. The ancestors of common bean (Phaseolus vulgaris L.) cultivars are the wild common beans. Because wild beans adapt and survive well in the natural environment, it is hypothesized that wild common bean roots are less affected than those of domesticated beans at low substrate water potential $\left(\psi_{\mathrm{W}}\right)$. A wild common bean accession from Chihuahua Mexico and cv. Bayomex were studied. Seedlings with a mean root length between 3 and $4 \mathrm{~cm}$ were maintained for $24 \mathrm{~h}$ in vermiculite at $\psi_{\mathrm{W}}$ of -0.03 (well hydrated), $-0.65,-1.48$ and -2.35 $\mathrm{MPa}$ (partially dry). Ten anatomical characteristics of differentiation and cell division in root regions were evaluated. Thickness of epidermis and protoderm diminished similarly in wild and domesticated beans growing at low substrate $\psi_{\mathrm{W}}$ (between - 0.65 and -2.35 $\mathrm{MPa}$ ). At the same time, parenchymatic cell area diminished by $71 \%$ in the domesticated variety, but by only $32 \%$ in the wild bean at $-2.35 \mathrm{MPa}$. The number of cells in the cortex and the thickness of the xylem wall increased in both wild and domesticated beans at low substrate $\psi_{W}$; nevertheless, the effect was significantly lower in the wild bean. The number of xylem vessels increased in the cultivar (up to $40 \%$ ) while in the wild bean it decreased (up to $33 \%$ ). The diameter of xylem vessels and transverse root area diminished (15 and $57 \%$, respectively) in the cultivar, but in the wild common bean were not affected. Anatomical root characteristics and their modifications in both differentiation and cell division in root regions demonstrated that the wild bean reacted quite differently to substrate $\psi_{\mathrm{W}}$ than the domesticated common bean.
\end{abstract}

Key terms: Endodermis, protoderm, seedlings, water potential, xylem.

\section{INTRODUCTION}

The importance of the common bean (Phaseolus vulgaris L.) throughout the world is remarkable. By 2007 dry beans were grown on 28.2 million ha, in 120 countries, with a total production of 20.1 million tons (FAO, http:/ / faostat.fao.org/ site/567/default.aspx; February 14, 2010). In addition, the common bean is the most important grain legume for direct human consumption in the developing world, mainly because it is a major source of low cost protein. Drought is a major constraint to common bean production in many countries. The common bean is highly susceptible to drought stress. Depending on the severity of the water deficit, drought affects the plant directly by dehydration, and indirectly, by reducing nutrient absorption (Hose et al., 2001). The common bean is cultivated in regions where water deficits can significantly reduce growth and yield. Drought affects global common bean production by $60 \%$ (Terán and Singh, 2002; Urrea et al., 2009). Consequently, there are efforts to obtain drought resistant $P$. vulgaris cultivars (Urrea et al., 2009). The ancestors of common bean cultivars are the wild common beans; Mexico is one of the two centers of origin and has a great diversity of wild bean populations. Domestication favored anthropocentric features like larger seeds, loss of dehiscence, loss of dormancy, reducing or eliminating anti-physiological factors, and others like increased seed color diversity or culinary features, yet it seems these were trade-off features associated with the cultivation environment. It has been observed that some wild populations are tolerant to low substrate water potential $\left(\Psi_{\mathrm{W}}\right)$, probably because of natural adaptation to semi-arid conditions. Consequently, wild beans could be a good source of genetic pools to improve current common bean cultivars (Sánchez-Urdaneta et al., 2003 and 2004a; Arroyo-Peña et al., 2005).

Given the above, it is very important to understand the anatomical, biochemical and physiological response of the common bean to drought, especially under the effects of climatic change and in the context of food security issues (Intergovernmental Panel on Climate Change, 2007a-b). A mayor benefit of wild type usage is enhanced biological diversity and richness without the transgenic of highly mechanized agricultural processes, considering the relevance of this seed for developing countries where agriculture is less technology-intensive.

The anatomical responses of plants to water deficit are diverse and depend on adaptive characteristics expressed through diverse mechanisms. Roots can be compared to sensors that detect changes in soil $\psi_{\mathrm{W}}$ through tissue dehydration and play an important role in plant resistance to water deficit (Shao et al., 2008). The root anatomy of plants growing under water deficit is still only partially known, mainly because of the difficulty of obtaining intact roots and the root-to-shoot interaction during development. However, it has been documented that changes in the anatomy of root tissue result from moderate or high water deficit. These are adaptive strategies of plants to survive in adverse environments (Shao et al., 2008). 
Young seedlings with undeveloped shoots of the common bean (Phaseolus vulgaris L.) (Sánchez-Urdaneta et al., 2003 and 2004a), maize (Zea mays L.) (Peña-Valdivia et al., 2005; Sánchez-Urdaneta et al., 2005) and maguey (Agave salmiana) (Sánchez-Urdaneta et al., 2004b; Peña-Valdivia and Sánchez-Urdaneta, 2009) have been used to study root reaction to substrate $\psi_{\mathrm{W}}$. For instance, when comparing drought sensitive and drought tolerant maize cultivars, it has been observed that root seedlings growing at substrate $\Psi_{\mathrm{W}}$ of $-2.35 \mathrm{MPa}$ decreased transverse root area, thickness of epidermis, exodermis and cortex, and the number of cells in the cortex and metaxylem vessels compared to seedlings growing at $-0.03 \mathrm{MPa}$. However, protoderm and cortex thickness were affected only in the drought sensitive maize (Peña-Valdivia et al., 2005). Some of the above root anatomical responses seem to be adaptations that enhance plant survival in hostile environments (Da Silva et al., 2003).

The aim of this research was to evaluate anatomical changes in root seedlings of a wild accession and a cultivar of common bean (P. vulgaris L.) under different substrate $\psi_{\mathrm{W}}$ and in laboratory growth conditions, in order to test the hypothesis that roots of the wild common bean are less affected than the domesticated type at low $\psi_{\mathrm{W}}$.

\section{MATERIALS AND METHODS}

\section{Plant Material}

The cv. Bayomex and a wild common bean accession $(P$. vulgaris L.) from Chihuahua, Mexico, were evaluated. They were chosen because contrasting reactions to low substrate $\psi_{\mathrm{W}}$ in root seedlings have been reported, taking into account growth, relative water content, damage index of cellular membranes, and electrolyte leakage (Sánchez-Urdaneta et al., 2003 and 2004a).

The cv. Bayomex was developed by the INIFAP (National Institute for Research in Agriculture, Forestry and Animal Husbandry, Mexico) for cultivation in dry land areas. Wild seeds (accession G22837 coded at the International Centre of Tropical Agriculture) were originally collected from Chihuahua, Mexico (26 $56^{\prime}$ Lat. N, $106^{\circ} 25^{\prime}$ Long. E, 1750 m.a.s.l., and BS1 kw (w)(e $\left.\mathrm{e}^{\prime}\right)$ climate or semidry temperate climate). Seeds were multiplied in an experimental field at the Colegio de Postgraduados in Montecillo, Mexico (19 $31^{\prime}$ Lat. N, 98 $53^{\circ}$ Long. W and 2353 m.a.s.1.), during the spring-summer season and were kept refrigerated at $5 \pm 1{ }^{\circ} \mathrm{C}$ and $20 \% \mathrm{RH}$ for several days until the research began.

\section{Experimental design and statistical analysis}

The experiment was conducted with a completely random design with a factorial treatment arrangement. Evaluated factors and levels were: common bean type (wild and domesticated) and substrate $\Psi_{\mathrm{W}}(-0.03,-0.65,-1.48$ and -2.35 $\mathrm{MPa})$. Each experimental unit was a group of seven seedlings, three sub-samples were obtained from each root, and the experiment was replicated four times. Data were submitted to an analysis of variance, mean multiple comparisons with Tukey's HSD test and Pearson correlation test. As well, a principal components multivariable analysis was carried out to identify which variables were the most important to describe the effects of $\Psi_{W}$ on root anatomy. Statistical analysis was performed with SAS software (SAS Institute, 1999-2000, version 8.1). Data graphic representation was obtained using the SigmaPlot software (Jandel Scientific, version 9). The GenStat for Teaching software (VSN International Ltd) was used to investigate the linear regression relationship between root anatomical characteristics and $\psi_{\mathrm{W}}$.

\section{Experimental}

Seeds were germinated at $25 \pm 1{ }^{\circ} \mathrm{C}$ in darkness as described by Peña-Valdivia et al. (2002). Root seedling length, after 72 $\mathrm{h}$ of germination, was between 30 and $40 \mathrm{~mm}$. In order to quantify root growth during the next $24-48 \mathrm{~h}$, a mark was made $2 \mathrm{~mm}$ over the apex with a paintbrush and black ink, since longitudinal root growth of the common bean mainly occurs in the first $2 \mathrm{~mm}$ from the apex (Garcia-Nava et al., 1999). Seedlings were then transplanted into polyvinylchloride containers $(40 \mathrm{~mm}$ inside diameter and $100 \mathrm{~mm}$ length) filled with vermiculite at different $\psi_{\mathrm{W}}$. Each container was covered with a removable black polyethylene lid, fixed with an elastic band in order to keep a constant $\psi_{\mathrm{W}}$. All procedures were carried out in darkness. Containers were then maintained in dark conditions at $25 \pm 1{ }^{\circ} \mathrm{C}$ for 24 $h$, roots were then harvested and anatomical characteristics were evaluated.

Vermiculite at $\psi_{\mathrm{W}}$ of $-0.03,-0.65,-1.48$ and $-2.35 \mathrm{MPa}$ was obtained by mixing dry vermiculite with 100, 10, 8 and 6 parts of distilled water (w:v) respectively, and then maintained in polyethylene bags for a period of $48 \mathrm{~h}$ before the start of the experiment. After this time, each vermiculite $\psi_{\mathrm{W}}$ was determined using psychrometric chambers (Wescon C-52, Inc, Utha, USA) during $4 \mathrm{~h}$; vermiculite $\psi_{\mathrm{w}}$ was determined by connecting the chambers to a microvoltmeter (Wescon HR-33T, Inc., Utha, USA) operated in the dew point mode (Sánchez-Urdaneta et al., 2005).

Anatomical characteristics were evaluated in two root sections, the first centimetre of the root apex, including the cell division root region, and an upper section, the differentiation root region. Tissues were fixed in an acetic acid:formaldehyde:ethanol:water solution (FAA, 5:10:52:33), in a 10:1 (w:v) fixer:sample relation, for a 4 to $6 \mathrm{~d}$ period, and then dehydrated with butyl alcohol, followed by embedding in paraffin. Samples were sectioned into $10 \mu \mathrm{m}$ ribbons and mounted on glass slides with chrome adhesive. Staining was made using a safranin-fast green stain system following Johansen (1974, cited by Peña-Valdivia et al., 2005). The observation and analysis of preparations were conducted in an inverted optimum microscope (ZEISS, Axiovert 25), equipped with a video camera (SONY SSC-DC54). Dimensions and number of anatomical structures (transverse root area, parenchymatic cell area, xylem vessel diameter, thickness of protoderm, thickness of epidermis, thickness of xylem wall, parenchymatic cell number and xylem vessel number) were obtained from images captured with a video camera using the Image Tool 3.0 software for PC (Wilcox et al., 2002).

\section{RESULTS AND DISCUSSION}

Research and practices aimed at improving water-stress resistance and water-use efficiency in plants have been 
carried out for many years, yet the plant mechanism involved is still not clear. Knowledge of the biochemical, molecular and morphological responses to drought is essential for a holistic interpretation of the resistance mechanisms to water-limited conditions in higher plants (Shao et al., 2008). Among the main functions roots perform is nutrient uptake from the soil. Proper root performance relies on certain specialized cortical layers (e.g. the endodermis and exodermis act as ions filters) (Ma and Peterson, 2003). Water deficit triggers a wide variety of root responses, so that changes in root growth can explain alterations in cellular metabolism and plant productivity. Plants growth and hydraulic changes can be understood by better knowing anatomical root modifications. In our view, there is insufficient information about the changes in root anatomical as reaction to water deficit (Peña-Valdivia et al., 2005; Peña-Valdivia and Sánchez-Urdaneta, 2009).

\section{Transverse root area}

The transverse root section was circular in both wild and domesticated common beans only at $-0.03 \mathrm{MPa}$ (fully hydrated substrate). It is noteworthy that at this $\psi_{\mathrm{W}}$ the transverse root area of the domesticated bean was significantly higher compared to that of the wild bean (between 31 and $93 \%$ in differentiation and cell division root regions, respectively). Low substrate $\psi_{\mathrm{W}}$ negatively affected the transverse root area, mostly at the differentiation region in both common beans. This effect was different between domesticated and wild bean, since only in the former the change followed a linear decay $\left(y=0.15 x+0.07, R^{2}=0.61, P<0.01\right)$ (Figure $\left.1 A\right)$. The lowest $\psi_{\mathrm{W}}(-2.35 \mathrm{MPa}$; partially hydrated substrate, $6 \%$ water $)$ diminished by $57 \%$ transverse root area at the differentiation region of domesticated bean; in contrast, the reduction in wild bean averaged $31 \%$, at this $\psi_{\mathrm{W}}$. Both beans reached a similar transverse root area $\left(0.4 \mathrm{~mm}^{2}\right)$. The transverse root area of the cell division region was less affected at lower $\psi_{\mathrm{W}}$ (up to $26 \%$ ) than the differentiation region in the domesticated bean; in contrast, the wild bean was not affected. These observations demonstrate that transverse root growth of the wild bean was less and differently affected than the domesticated bean by low substrate $\psi_{\mathrm{W}}$. This could be the result of wild bean adaptation to adverse environments, including low water availability because of erratic precipitation and/or water competition with neighboring vegetation. The result is that wild beans seem more tolerant to water deficit than the domesticated ones (Sánchez-Urdaneta et al., 2004 b; Arroyo-Peña et al., 2005). An irregular transverse root shape (compare Figure 2 A-B and 3 A-B to 2 D-E and 3 D-E), with a smaller area, was observed with all $\psi_{\mathrm{W}}$ lower than $0.03 \mathrm{MPa}$.

In the present study, the highest reaction to low substrate $\psi_{\mathrm{W}}$ of differentiation root region with respect to cell division was observed in the transverse root area; this was also observed in maize seedling roots of $\mathrm{cv}$. Tuxpeño C0 and Tuxpeño C8, drought sensitive and tolerant, respectively (Peña-Valdivia et al., 2005). This can be interpreted as a seedling root reaction to low substrate $\psi_{\mathrm{W}}$, representing a strategy that is widespread among higher plant species.

\section{Root epidermis and protoderm}

Epidermis thickness was statistically similar in both wild and domesticated beans at $-0.03 \mathrm{MPa}$. The epidermis is the outermost root layer, where water and non-selective mineral intake can potentially move apoplastically through its walls (Hose et al., 2001). This area absorbs water from the soil in mature and still young parts of the root (North and Peterson, 2005). Low substrate $\psi_{W}$ affected epidermis thickness similarly and with the same intensity in both cultivar and wild accession. A linear relationship between epidermis thickness and $\psi_{\mathrm{W}}$ was observed in both cultivar $\left(\mathrm{y}=10.67 \mathrm{x}+39.88, \quad \mathrm{R}^{2}=0.70, \quad \mathrm{P}<0.01\right)$ and wild bean $\left(y=48.32 x+11.44, R^{2}=0.74, P<0.01\right)$, both diminished up to $35 \%$ at the lowest substrate $\psi_{\mathrm{W}}$ (Figure $1 \mathrm{~B}$ ). A similar reaction was

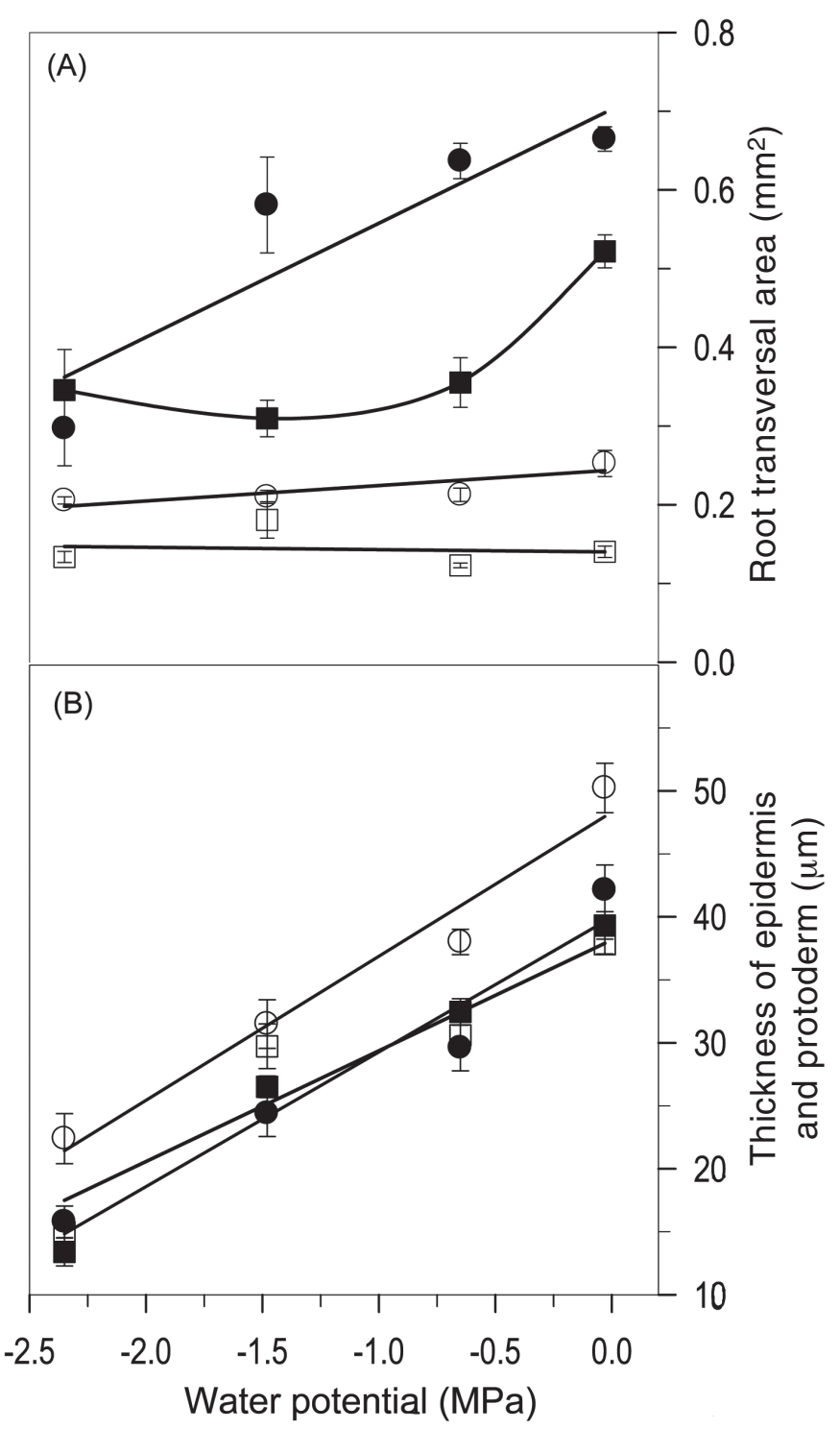

Figure 1: Effects of substrate water potential in (A) root transversal area and (B) epidermis and protoderm thickness in differentiation root region $(\bullet, \boldsymbol{)})$ and cell division root region $(0, \square)$ of common bean Phaseolus vulgaris L. seedlings (wild accession from Chihuahua, Mexico $=\square, \square$; and domesticated $=$ cv. Bayomex, $\bullet, 0)$. Each point represents the average of seven repetitions \pm the standard error $(n=28)$. 

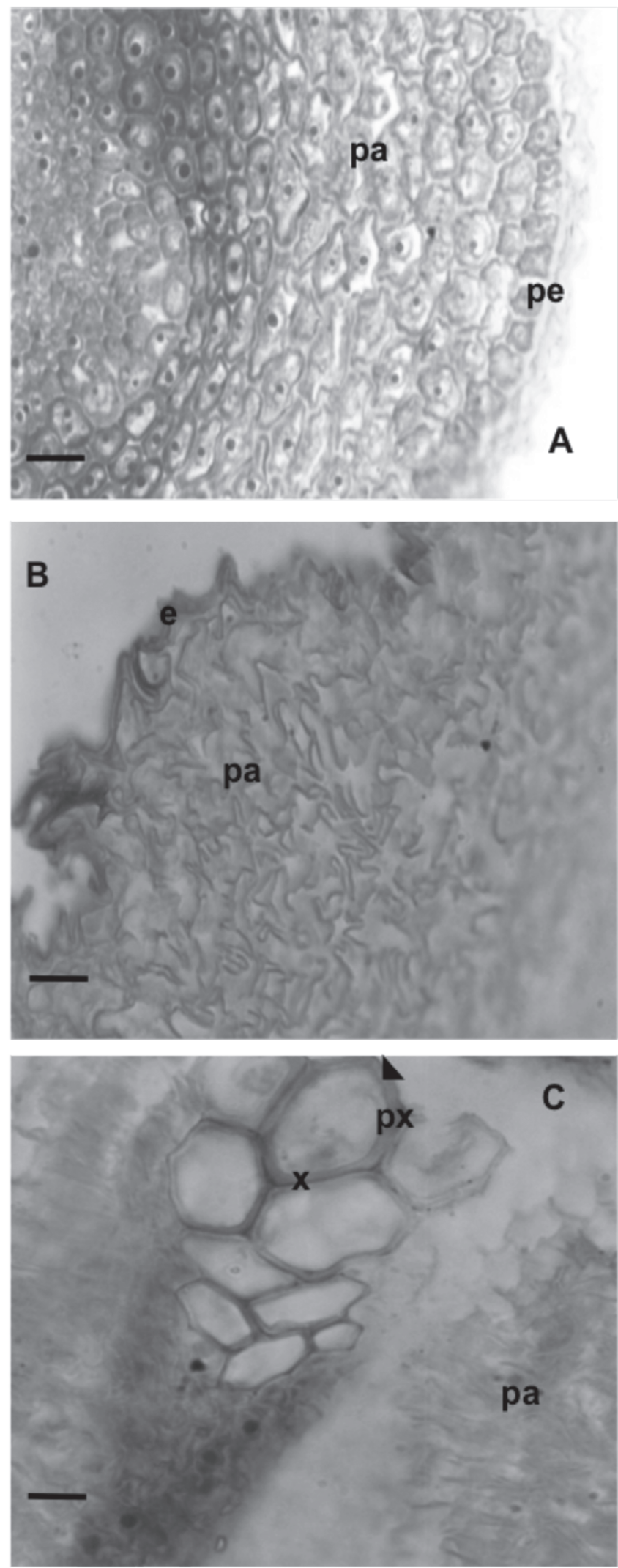
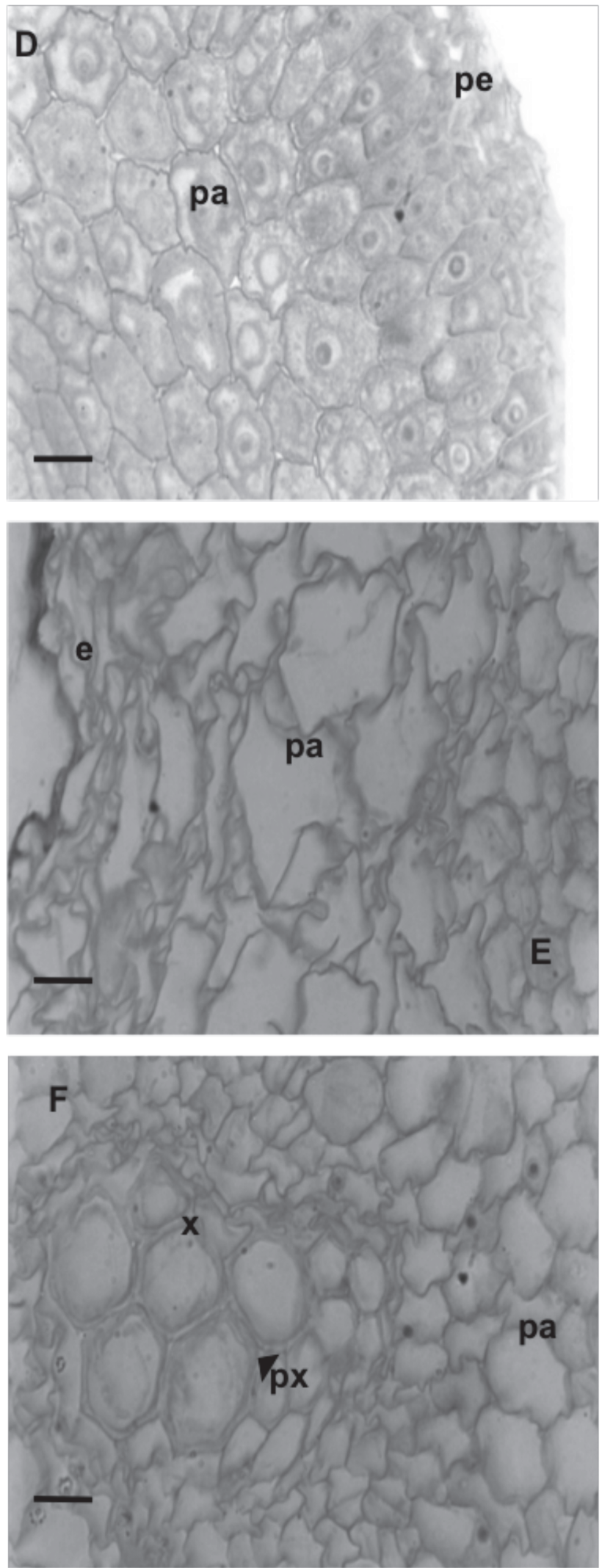

Figure 2: Cross section of cell division root region ( $A$ and $D$ ) and differentiation root region ( $B, C, E$ and $F$ ) of domesticated (cv. Bayomex) common bean (Phaseolus vulgaris L.) seedlings growing in vermiculite at $\psi_{\mathrm{w}}$ of $-2.35 \mathrm{MPa}(\mathrm{A}, \mathrm{B}$ and $\mathrm{C})$ and $-0.03 \mathrm{MPa}(\mathrm{D}$, E and F). Epidermis: e; parenchyma: pa; protoderm: pe; xylem wall: px; xylem: $x$ ). Scale marker $=60 \mu \mathrm{m}$. 
observed in maize and maguey (monocot species) root seedlings independently of drought tolerance (Peña-Valdivia et al., 2005; Peña-Valdivia and Sánchez-Urdaneta, 2009). Thus, epidermis root reaction to low substrate $\psi_{\mathrm{W}}$ is similar in both monocots and dicots (as in wild and domesticated beans).

The protoderm (thin outer layer of the growing points of the root that gives rise to the epidermis) in the domesticated bean reached higher $(35 \%)$ radial growth than in the wild bean at $-0.03 \mathrm{MPa}$. A similar negative linear relationship was observed between protoderm thickness and substrate $\psi_{\mathrm{W}}$ in both domesticated and wild beans $(\mathrm{y}=10.66 \mathrm{x}+39.88$, $\mathrm{R}^{2}=0.87$; and $\mathrm{y}=8.80 \mathrm{x}+37.98, \mathrm{R}^{2}=0.75, \mathrm{P}<0.01$, respectively). The most remarkable decrease in protoderm thickness $(57 \%)$ was at $-2.35 \mathrm{MPa}$, in both beans, and likewise with the epidermis. A significant interaction $(\mathrm{P}=0.0001)$ between $\psi_{W}$ and bean type, in both epidermis and protoderm thickness, confirmed the anatomical modifications in both structures regardless of bean type. Epidermis and protoderm thickness in wild bean roots were significantly similar at each substrate $\psi_{\mathrm{W}}$. In contrast, the protoderm in the cultivar roots was wider than the epidermis, although the difference was almost constant independent of the substrate $\psi_{\mathrm{W}}$ (Figure 1B). In recent research we have found that seedling protoderm thickness was affected by low substrate $\psi_{W}$ in a drought sensitive maize cultivar (Tuxpeño Seq. C0), while no changes occurred in a drought tolerant one (Tuxpeño Seq. C8) (PeñaValdivia et al., 2005). On other hand, in plants characterized as drought tolerant, such as maguey, the effect of low substrate $\psi_{\mathrm{W}}$ on protoderm thickness is insignificant (PeñaValdivia and Sánchez-Urdaneta, 2009). Once again, these results indicate that this type of protoderm alteration is part of a drought tolerance strategy.

Root epidermis and protoderm showed stratification (i.e. deposition of material in successive cell wall layers, thus giving rise to a stratified appearance) in both bean types. Large intercellular spaces suggest that gas exchange is critical in this area for respiration (Figures $2 \mathrm{~B}$ and E, $3 \mathrm{~B}$ and E). In both root regions, mostly at low $\psi_{\mathrm{W}}(-2.35 \mathrm{MPa})$, cellular plasmolysis was observed, epidermal cells collapsed, and cells appeared to die in some root areas (compare Figures $2 \mathrm{~A}$ and $3 \mathrm{~A}$, at $-2.35 \mathrm{MPa}$ with Figures $2 \mathrm{D}$ and $3 \mathrm{D}$, at $-0.03 \mathrm{MPa}$ ). In the present study, exodermis (the principal apoplastic barrier being located at the endodermis where the Casparian band minimizes unrestricted access of water and solutes to the stellar tissues; Hose et al., 2001) in the roots of common bean seedlings were detected closer to protoderm (Figure $2 \mathrm{~A}$ and D, $3 \mathrm{~A}$ and D).

The effects of environmental stress are determined by all plant cells, resulting in structural and functional alteration to cell integrity. Hose et al. (2001) pointed out the importance of the role short cells (passage cells) of the exodermis in the transport of materials after cellular death in the epidermis, and in cellular survival of the exodermis in some areas of the cortex and stele of onion (Allium cepa) roots after dry periods.

\section{Parenchyma}

Only at $\psi_{\mathrm{W}}$ of $-0.03 \mathrm{MPa}$ was a typical isodiametric shape of parenchymatic cells observed in both root regions and in both wild and domesticated beans (Figure $2 \mathrm{~A}$ and D and $3 \mathrm{~A}$ and D). Modification of the isodiametric shape of parenchymatic cells was observed in dehydrated root seedlings growing under lower substrate $\psi_{\mathrm{W}}$ (Figure $2 \mathrm{~A}$ and $\mathrm{B}, 3 \mathrm{~A}$ and B). Similar results for maize seedling roots were reported, including reduction of cortical cell size and modification of root shape when the relative water content reached a value of 0.5 (Facette et al., 1999).

The parenchymatic cell area in the domesticated common bean was significantly larger $(20.6 \%)$ than in the wild bean at $-0.03 \mathrm{MPa}$ (Figure $4 \mathrm{~A}$ ). Low $\psi_{\mathrm{W}}$ diminished this characteristic in both bean types, and in different proportions. The domesticated common bean was more affected than the wild one; hence the reduction in the former was substrate $\psi_{\mathrm{W}}$ dependent (e.g. statistically significant linear trend was detected; $\mathrm{y}=48.32 \mathrm{x}+11.44, \mathrm{R}^{2}=0.8156$ $\mathrm{P}<0.01$ ), and reached up to $71 \%$ at $-2.35 \mathrm{MPa}$. On the contrary, in the wild bean, it diminished only $38 \%$ at each substrate $\psi_{\mathrm{W}}$ lower than $-0.03 \mathrm{MPa}$ (Figure $4 \mathrm{~A}$ ). These results also indicate that roots of the domesticated common bean had more profound anatomical changes at low vermiculite $\psi_{\mathrm{W}}$ than did the wild common bean.

The differentiation zone of roots can be radially divided into an inner part that comprises the stele and an outer part that is defined by multiple layers of parenchymal tissue and a single epidermal layer that connects the root with the exterior soil environment (Saleem et al., 2010). Cortical parenchyma is the fundamental part of primary root body and represents structurally and functionally an important constituent of the root. It might serve as a storage area of nutrients and water, and at least in younger sections of root fulfills metabolic functions that are not yet well understood (Lux et al., 2004; Saleem et al., 2010). As to the higher root parenchymatic cell area, at $-0.03 \mathrm{MPa}$, the drastic reduction displayed by seedlings of the domesticated common bean when exposed to low substrate $\psi_{\mathrm{W}}$ imply an important role in determining reactions to drought in the root. The distinctive parenchymatic cell area at higher substrate $\psi_{\mathrm{W}}$ and the non-linear drop of the parenchymatic cell area at low substrate $\psi_{\mathrm{W}}$ suggests a different drought reaction between wild root seedlings and domesticated ones.

Plasmolyzed epidermal and parenchymatic cells were observed in both division and differentiation root regions, and were more evident at $\psi_{\mathrm{W}}$ lower than $-0.03 \mathrm{MPa}$ and at $-2.35 \mathrm{MPa}$ (observe that plasma membrane pulled away from the cell wall in Figures $2 \mathrm{C}$ and $3 \mathrm{C}$ contrariwise to $2 \mathrm{D}$ and 3 D). Plasmolized cells were more evident in the domesticated common bean than in the wild bean; by contrast, in the stele a similar alteration was almost imperceptible.

The lowest substrate $\psi_{\mathrm{W}}$ seemed to increase the parenchymatic wall thickness in both root regions, though the increase was not quantified. Furthermore, an almost total disconnection between adjacent cells and wide intercellular spaces was observed at $-2.35 \mathrm{MPa}$ (Figure $2 \mathrm{C}$ and F, $3 \mathrm{C}$ and F). A similar effect in the cortex of differentiation root region in drought stressed maize has been noted; and cortex cells of the cell division region of these roots gradually died in a centripetal pattern, and cellular distortion increased with stress, probably due to sclerification (the process of changing into sclerenchyma by progressive lignification of secondary walls) of cells outside the cortex (Lux et al., 2004).

The domesticated and wild common bean had a similar number of cells in the cortical parenchyma in both root regions at a $\psi_{\mathrm{W}}$ of $-0.03 \mathrm{MPa}$. Still, the root cell division 

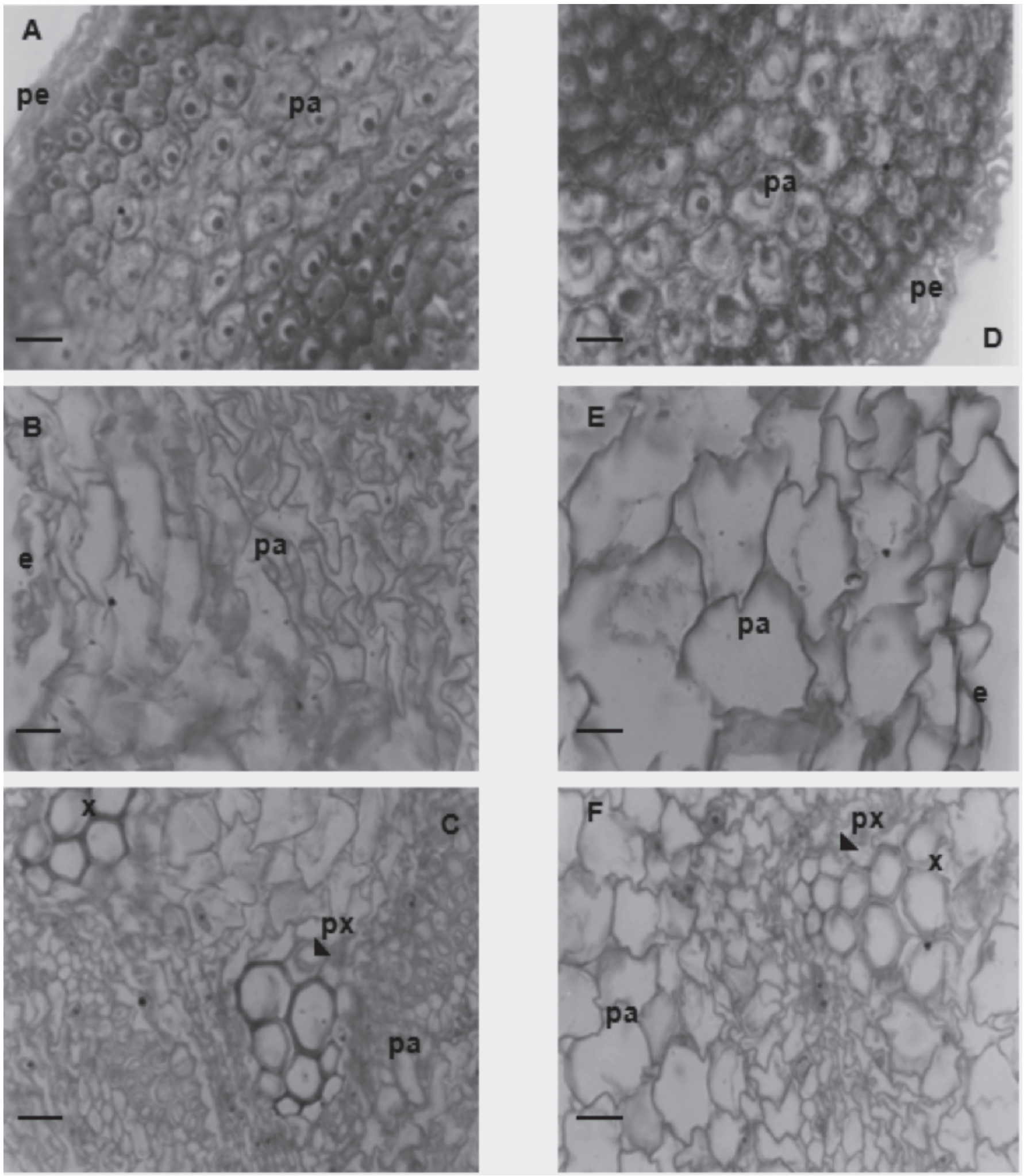

Figure 3: Cross section of cell division root region ( $A$ and $D)$ and differentiation root region ( $B, C, E$ and $F)$ of wild common bean (Phaseolus vulgaris L.; from Chihuahua, Mexico) seedlings growing in vermiculite at $\psi_{\mathrm{w}}$ of $-2.35 \mathrm{MPa}(\mathrm{A}, \mathrm{B}$ and $\mathrm{C})$ and $-0.03 \mathrm{MPa}(\mathrm{D}$, E and F). Epidermis: e; parenchyma: pa; protoderm: pe; xylem wall: px; xylem: x). Scale marker $=60 \mu \mathrm{m}$. 
region almost doubled compared to the differentiation root region (Figure $4 \mathrm{~B}$ ). Low substrate $\psi_{\mathrm{W}}$ significantly increased the number of root cells in the cortex, although in different proportions, in both root regions of both bean types. In all cases, a statistically significant $(\mathrm{P}<0.01)$ linear trend was detected. In the cell division region $\left(y=2.73 x-1.19, R^{2}=0.78\right)$ and in the differentiation region $\left(y=1.12 x-2.22, R^{2}=0.78\right)$ the maximum increases were 2.7 and 4.4 times. In the wild common bean a less drastic increase of 1.4 and 2.3 times was obtained in the cell division root region and the differentiation root region $\left(y=3.37 x-0.90, R^{2}=0.81\right.$ and $\left.\mathrm{y}=1.38 \mathrm{x}-1.53, \mathrm{R}^{2}=0.94\right)$ respectively, at $-2.35 \mathrm{MPa}$ compared to $-0.03 \mathrm{MPa}$ (Figure $4 \mathrm{~B}$ ). An increase in the number of

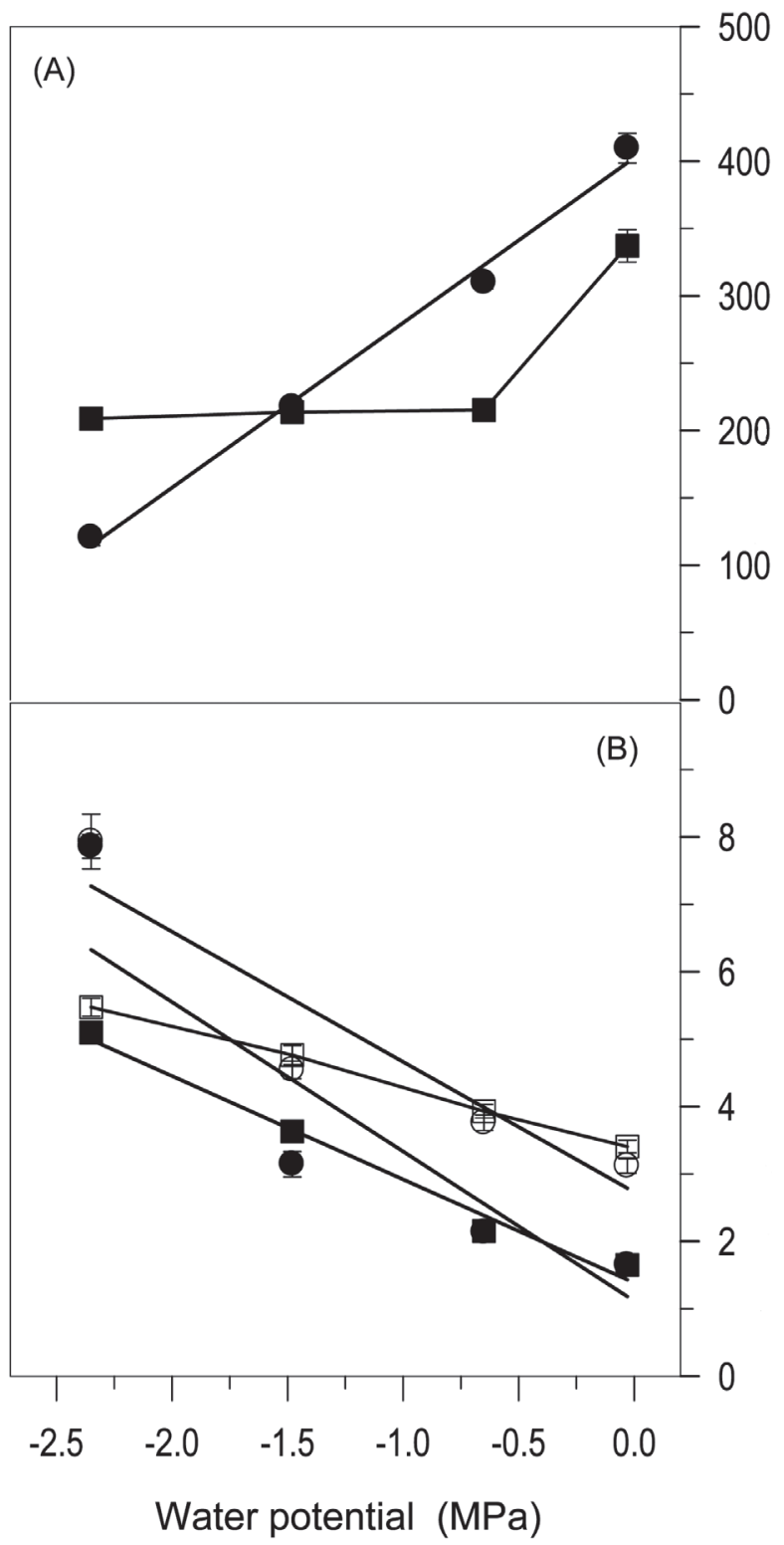

Figure 4: Effects of substrate water potential in (A) parenchymatic cell area and (B) number of cells in the cortex of differentiation root region $(\bullet, \boldsymbol{v})$ and cell division root region $(0, \square)$ of common bean Phaseolus vulgaris L. seedlings (wild accession from Chihuahua, Mexico $=$ Mexico $=\square, \square$, and domesticated $=\mathrm{cv}$. Bayomex, $\bullet, 0)$. Each point represents the average of seven repetitions \pm the standard error $(n=28)$. parenchymatic cells as a reaction to low substrate $\psi_{\mathrm{W}}$ was evident, indicating that root tissue dehydration accelerates cellular division; a remarkable difference is that the wild common bean reacted less drastically than the domesticated one. The increase of the number of cells in cortical parenchyma as a seedling reaction to low substrate $\psi_{\mathrm{W}}$, like that observed in domesticated and wild common beans, has also been reported in the cell division region and differentiation region of maize and agave root seedlings (Peña-Valdivia et al., 2005; Peña-Valdivia and SánchezUrdaneta, 2009). These results indicate that these root reactions to low substrate $\psi_{\mathrm{W}}$ are also a general phenomenon in seedlings of monocot and dicot species.

\section{Endodermis and stele}

In both wild and domesticated common beans, the stele in the cell division root region presented a star shape with four arms (tetrarca) branching out from a common centre, which can be surrounded by the pericycle and the endodermis. However, these two structures were not clearly distinguishable, perhaps due to the immaturity of apex tissue. As well, cell layers were observed surrounding the stele (Figures $2 \mathrm{~A}$ and D, $3 \mathrm{~A}$ and D).

In the present study the endodermis and the pericycle were not observed in cell division or differentiation root regions of any common bean; and intact exodermis and stele were observed only in the cell division region. In contrast, root endodermis and reduction of its thickness were clearly observed as a reaction to low substrate $\psi_{\mathrm{W}}$ in drought sensitive and drought tolerant maize seedlings (PeñaValdivia et al., 2005).

The functions of cortical tissues are diverse. The endodermis, and to some extent the exodermis, represents apoplastic barriers that control uptake and radial transport of water and solutes by the roots. These layers have additional functions, such as mechanically protecting the stele, as well as protecting against pathogens and parasites. The mid-cortex, or mesodermis, is the primary site for reserve material deposition. The cortex might be designated a root buffer zone, especially under stress conditions (Lux et al., 2004). For these reasons, knowing the changes occurring in cortical tissue of wild and domesticated common beans as reaction to water deficit helps us to understand the changes occurred during domestication.

Vascular tissue

Some anatomical characteristics related to water flow capacity and its efficient movement were quantified in the differentiation root region. The number of root xylem vessels was significantly higher $(40 \%)$ in the wild common bean than in the domesticated one at $\psi_{W}$ of $-0.03 \mathrm{MPa}$. These structures increased up to $24 \%$ at $\psi_{\mathrm{W}}$ of -1.48 and $-2.35 \mathrm{MPa}$ in the domesticated bean. In contrast, a significant reduction (33\%) was observed in the number of xylem vessels in the wild common bean with all substrate $\psi_{\mathrm{W}}$ lower than -0.03 $\mathrm{MPa}$ (Figure $5 \mathrm{~A}$ ). This result could indicate that domesticated beans growing under high humidity conditions, as in an irrigated field, requires these structures less to conduct water in the plant, but under drought conditions, root xylem vessels must assure water conduction. 
Different reactions to substrate $\psi_{\mathrm{W}}$ between the two common bean types seems to be related to the strategies of each type to the environment in which they originally grew (meaning either a natural or agricultural environment, given the case). The number and size of vascular elements, as well as the number and size of vascular junctions, influence water flow, potential and efficiency, as larger xylem vessels conduct water with less resistance than smaller ones (Nicotra et al., 2002). Because of these changes in the quantity of xylem vessels, they should be considered along with other root modifications as a function of substrate $\psi_{\mathrm{W}}$.

Along with the above, xylem vessel diameter in the domesticated bean was $30 \%$ larger than in the wild bean. Only in the former diameter of xylem vessels dropped significantly at low substrate $\psi_{\mathrm{W}}$ (up to $15 \%$ at $-2.35 \mathrm{MPa}$ ); in contrast, wild bean under lower than $-0.03 \mathrm{MPa}$ substrate $\psi_{\mathrm{W}}$ had no significant changes (Figure $5 \mathrm{~B}$ ).

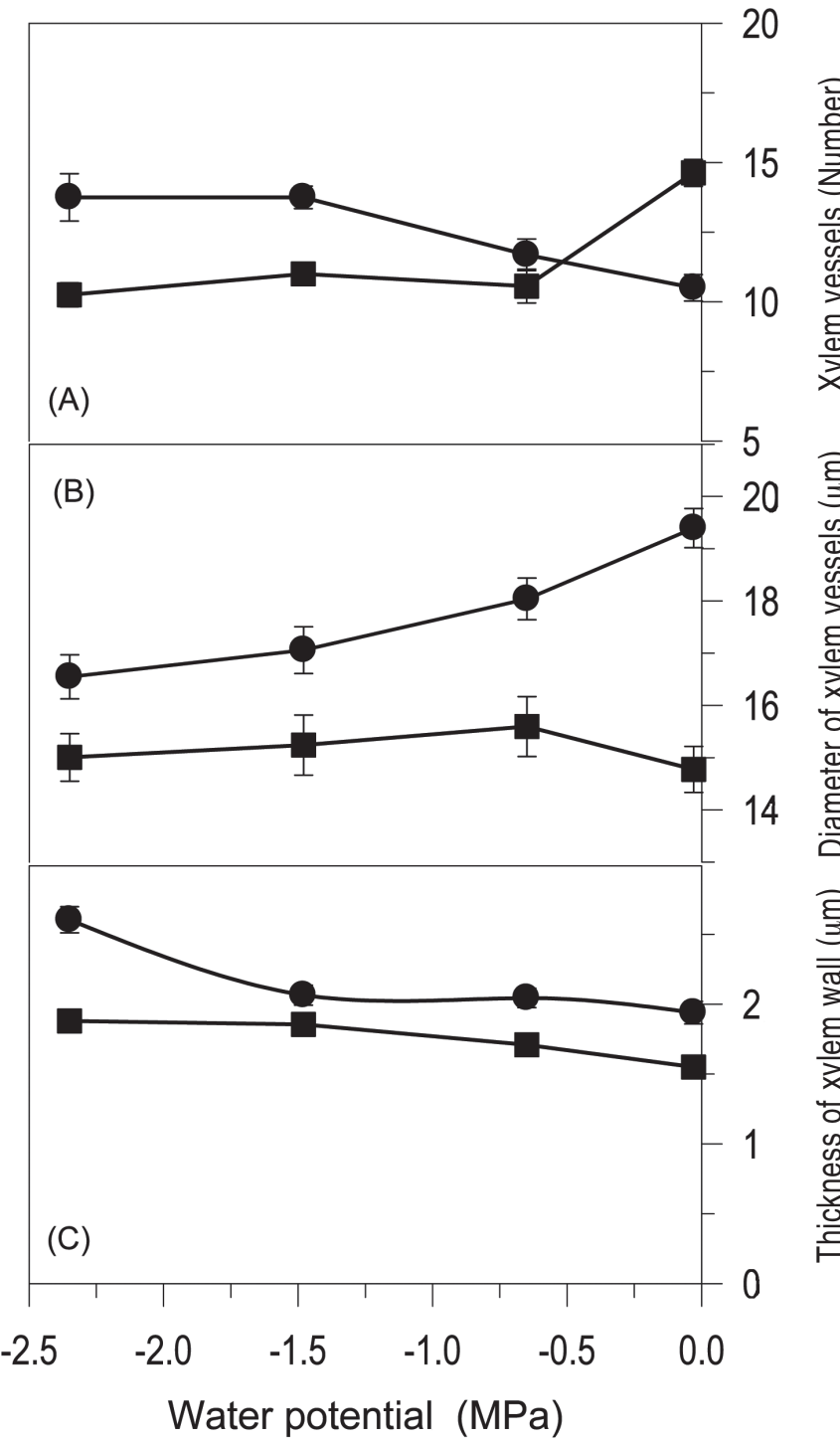

Figure 5: Effects of substrate water potential in (A) number of xylem vessels, (B) diameter of xylem vessels and (C) xylem wall thickness in differentiation root region of common bean (Phaseolus vulgaris L.) seedlings of cv. Bayomex (•) and a wild accession from Chihuahua ( $\boldsymbol{\square})$, Mexico. Each point represents the average of seven repetitions \pm the standard error $(n=28)$.
The xylem wall in domesticated bean was significantly thicker $(21 \%)$ than those in wild bean, when seedlings from both wild and domesticated beans grew in substrate at $\psi_{W}$ of $-0.03 \mathrm{MPa}$. Xylem wall thickness increased significantly, and with different intensity, in both bean types, as a reaction to low substrate $\psi_{\mathrm{W}}$. Increments of xylem wall thickness reached $39 \%$ and $16 \%$ in domesticated and wild beans, respectively. The domesticated bean had significantly thicker xylem walls than the wild bean, independently of $\psi_{W}$; the highest difference $(54 \%)$ was reached at $\psi_{\mathrm{W}}$ of $-2.35 \mathrm{MPa}$ (Figure 5C). Recently, it was observed that dry weight increases in roots of wild and domesticated common bean seedlings by the effect of restrictive $\psi_{\mathrm{W}}$ (Sanchez-Urdaneta et al., 2003), which can partially be explained by the growth of xylem cell walls (Facette et al., 1999).

Some substrate $\psi_{W}$ effects seem to be common in the anatomical characteristics of roots, independent of whether they are monocot or dicot species. Like the dicot in the present study, broader xylem vessels were present in monocot root seedlings, like maize (Zea mays L.) and maguey (Agave salmiana Otto ex Salm-Dyck) (Peña-Valdivia et al., 2005; Peña-Valdivia and Sánchez-Urdaneta, 2009) with substrate $\psi_{W}$ lower than $-0.03 \mathrm{MPa}$. In contrast, other characteristics are dissimilarly affected, as is the case of xylem vessel diameter, which significantly diminished in domesticated common bean (15\%; Figure $5 \mathrm{~B}$ ) and in $\mathrm{cv}$. Tuxpeño Seq. C0 (11 \%), drought-sensitive maize. Nevertheless, it increased (16\%) in cv. Tuxpeño Seq. C8, drought tolerant maize, in maguey (14\%) and it was not modified in the wild common bean (Figure 5 B). A similar heterogeneous response was observed in the number of xylem vessels of 11 Australian perennial plants with phylogenetically independent contrasts (Nicotra et al., 2002).

Species living in environments where water is available might only episodically have larger xylem vessels and larger diameter roots to maximize water uptake when it is available. However, large vessels may also be more prone to cavitation and embolism during water stress (Nicotra et al., 2002). Some evidence indicate that species with inherently low relative growth rates from arid zones may have smaller vessels in their roots than in species from mesic zones (Nicotra et al., 2002).

In common beans the vascular tissue in the differentiation root region presented four fascicules, separated by inter-fascicule parenchyma (Figures $2 \mathrm{C}$ and $\mathrm{F}$, $3 \mathrm{C}$ and F) and inter-xylem phloem; in contrast, corresponding layers belonging to endodermis, pericycle and vascular system were indistinguishable. This might be due to the development stage and/or root section observed. Substrate $\psi_{\mathrm{W}}$ between -0.65 and $-2.35 \mathrm{MPa}$ increased parenchyma cell plasmolysis of the stele, mainly at $\psi_{\mathrm{W}}$ of -1.48 and $-2.35 \mathrm{MPa}$ (compare Figures 2 and $3 \mathrm{~B}$ to 2 and $3 \mathrm{E}$ ).

\section{Principal components multivariate analysis}

To identify the variables that might be involved in the reactions of wild and domesticated common bean seedlings to substrate $\psi_{\mathrm{W}}$, we carried out the multivariate data analysis of principal components, which included anatomical characteristics. The first three principal components (PC) explained $74.3 \%$ of the variability (Table 1 ). The PC1 had a higher and positive correlation with only one anatomical 
characteristic of the differentiation root region (epidermis thickness) and three of the division root region (parenchymatic cell area, protoderm thickness and transverse area); while the PC1 has a negative correlation with the number of parenchymatic cells of both the differentiation and cell division regions. To all appearances, the CP1 was related to the entire process of mitosis, elongation and maturation occurring in the first centimeter of the root tip. Regarding the PC2, the contrary occurred, as it had a positive correlation with the diameter of the parenchymatic vessels and transverse area in both of the root regions.

\section{Table 1}

Eigenvalues and proportion of the variance explained for the first three principal components, generated from anatomical characteristics of wild and domesticated common bean seedlings under substrate $\psi_{w}$ between -0.03 and $-2.35 \mathrm{MPa}$.

\begin{tabular}{|c|c|c|c|}
\hline \multirow{2}{*}{$\begin{array}{l}\text { Principal } \\
\text { component }\end{array}$} & \multirow[t]{2}{*}{ Eigenvalue } & \multicolumn{2}{|c|}{ Proportion of variance explained } \\
\hline & & Individual & Cumulative \\
\hline 1 & 4.5914 & 0.4591 & 0.4591 \\
\hline 2 & 1.7375 & 0.1738 & 0.6329 \\
\hline 3 & 1.1008 & 0.1101 & 0.7430 \\
\hline
\end{tabular}

When the PC1 was plotted against the PC2 and PC3 and the third against the PC2, a small overlap was observed between the wild and domesticated common bean (Figure not shown); however, the triplot in Figure 6 clearly demonstrates the domesticated common bean and the wild accession to be independent biological units. Under the study conditions, the anatomical root characteristics that promoted independence related mainly to root growth (transversal area and cells quantity), water conduction and permeability (epidermis and xylem) in PC1. It is important to remember that the upper side of the meristem begins to elongate because of the absorption of large amounts of water into cell vacuoles. As cells stretch, they increase in length up to four times their original size, as this is the region where growth converts to length. Elongation provides force to push the root tip through soil (Ma and Peterson, 2003). The PC2 enhanced the common bean's separation. This PC was composed mainly of two characteristics of the root differentiation region (diameter of the parenchymatic vessels and the transverse area of both root regions). In these root regions cells mature and start changing their structure and function. Finally, PC3 had a high positive correlation (0.8522) with the number of xylem vessels in the root differentiation region. This is interpreted as a highly important characteristic for root reaction to low substrate $\Psi_{\mathrm{W}}$, and independent of the rest. Among the 10 anatomical characteristics, only thickness of the xylem wall had a low relative contribution to the first three $\mathrm{PC}$, and none of them made a high contribution for structuring more than one PC (Table 2). Anatomical modifications are needed in some plant tissues to continue physiological processes under stressful conditions. This is the case of xylem (diameter and number of vessels), which is the upward transportation system of water and dissolved nutrients.
The triplot in Figure 6 shows that it is possible to distinguish between domesticated and wild beans using anatomical root characteristics. This PC analysis shows clear differences between common beans, growing under low $\psi_{\mathrm{W}}$ (between -0.65 to $-2.35 \mathrm{MPa}$ ) or even at optimal substrate $\psi_{\mathrm{W}}$ of $-0.03 \mathrm{MPa}$. Furthermore, significant differences are also evident in the cell division and differentiation regions, ensuring a contrasting reaction at an anatomical level in the root to substrate $\psi_{\mathrm{W}}$ that occurred with domestication, as opposed to the wild common bean's adaptation to a fluctuating environment that includes erratic precipitation and competition for water with neighboring plants. Most variance at the root cell division and differentiation regions was captured in the first 3PC's (PC1: $45.91 \%$, PC2: $17.38 \%$ and PC3: $11.01 \%$ ), totaling $74.30 \%$ of the observed variance. In these seedling roots it was possible to differentiate specialized tissues (e.g. epidermis, endodermis), histological root region (cell division region and differentiation region), and the reaction of common bean seedlings to substrate $\psi_{\mathrm{W}}$ and that of wild and domesticated common bean to $\psi_{W}$ (Figure 6).

The results suggest that during the domestication process of the common bean a significant slimming of root protoderm took place, as well as an increase in the number and thickness of xylem vessels. It also seems that during domestication some root reactions to low substrate $\psi_{\mathrm{W}}$ have changed. Our results also indicate that protoxylem vessels in wild common bean roots are significantly thinner than those in domesticated common beans, this could be one of the most relevant characteristics that allows tolerance to low $\psi_{\mathrm{W}}$, as smaller vessel diameter could favor the tolerance of the wild common bean to water deficit, due to the axial resistance to water flux resistance.

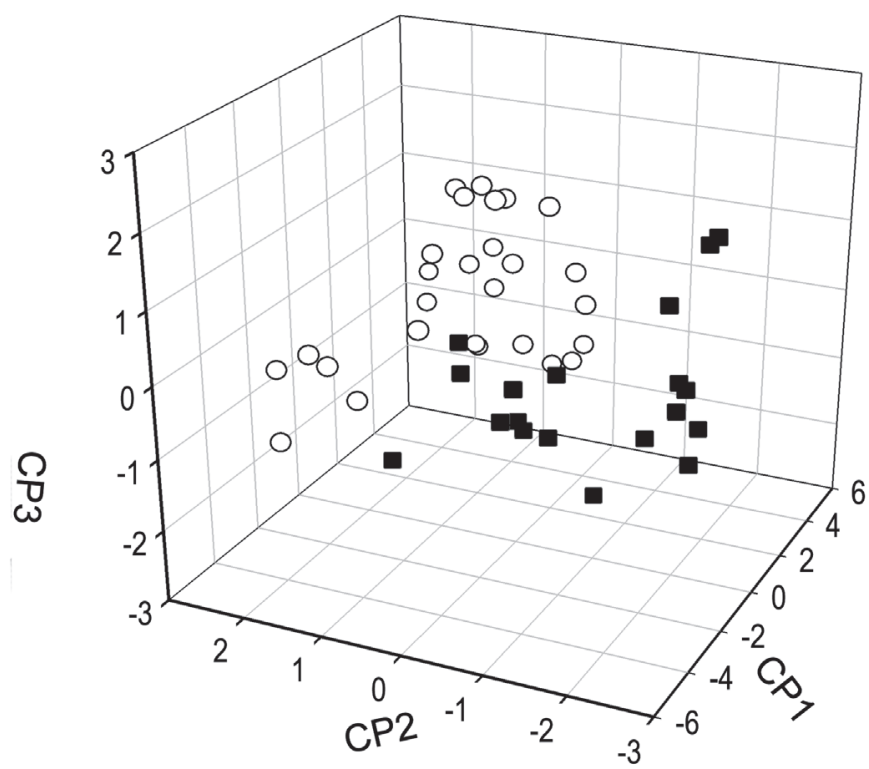

Figure 6: Ordination on the three axes or principal components (PC) of a domesticated (O; cv. Bayomex) and a wild ( $(\mathbf{C})$ common bean (Phaseolus vulgaris L.) accession from Chihuahua, Mexico, based on 10 anatomical root characteristics of seedlings under substrate $\psi_{\mathrm{w}}$ between -0.03 and $-2.35 \mathrm{MPa}$ $(n=28)$ 
Table 2

Eigenvectors for the first three principal components (PC) generated from anatomical characteristics of wild and domesticated common bean seedlings under substrate $\psi_{\mathrm{w}}$ between -0.03 and $-2.35 \mathrm{MPa}$.

\begin{tabular}{|c|c|c|c|}
\hline Root region and characteristic & $\mathrm{CP} 1$ & $\mathrm{CP} 2$ & $\mathrm{CP} 3$ \\
\hline \multicolumn{4}{|l|}{ Differentiation root region } \\
\hline Diameter of the parenchymatic vessels & 0.1753 & 0.5063 & -0.2285 \\
\hline Number of parenchymatic cells & -0.3894 & 0.3421 & -0.0435 \\
\hline Number of xylem vessels & -0.0420 & -0.1427 & 0.8522 \\
\hline Thickness of the epidermis & 0.3757 & -0.1981 & -0.1479 \\
\hline Thickness of the xylem wall & -0.0568 & 0.3065 & 0.3143 \\
\hline Transverse area & 0.1900 & 0.5688 & 0.1864 \\
\hline \multicolumn{4}{|l|}{ Division root region } \\
\hline Number of parenchymatic cells & -0.3875 & 0.3168 & -0.0539 \\
\hline Parenchymatic cell area & 0.4263 & 0.1437 & 0.0289 \\
\hline Protoderm thickness & 0.4127 & 0.0653 & -0.0574 \\
\hline Transverse area & 0.3650 & 0.1555 & 0.2393 \\
\hline
\end{tabular}

\section{CONCLUSIONS}

Substrate $\psi_{\mathrm{W}}$ between -0.65 and $-2.35 \mathrm{MPa}$ modified (epidermis and protoderm thickness), with different intensity (parenchymatic cell area, number of cortex cells and thickness of xylem wall), or different trends (number and diameter of xylem vessels and transverse root area) the anatomical root characteristics in the domesticated common bean seedlings compared to wild ones. A key finding was that the diameter of xylem vessels is decreased in the domesticated bean roots compared to those of the wild type, in which diameter was the same, from -0.03 to $-2.5 \mathrm{MPa}$. This means that wild beans do not reduce their growing root capacity at low $\psi_{\mathrm{W}}$. In general, the strongest reaction of domesticated common bean roots was observed at $\psi_{\mathrm{W}}$ of -2.35 MPa compared with the wild common bean. Multivariate PC analysis of anatomical root characteristics and their modifications in both differentiation and cell division regions as a reaction to low substrate $\psi_{\mathrm{W}}$ demonstrated that the wild common bean reacted quite differently from the domesticated one to low substrate $\psi_{W}$. This suggests that root anatomical changes during domestication negatively modified the capacity of the common bean to respond to drought stress.

\section{ACKNOWLEDGMENTS}

We are grateful to Biol. Baruch Arroyo P. for the critical reading of the manuscript and English revision.

\section{REFERENCES}

ARROYO-PEÑA B, PEÑA-VALDIVIA CB, SÁNCHEZ-URDANETA AB (2005) Efecto del potencial de agua en la germinación de semillas de frijol (Phaseolus vulgaris L.) silvestre y domesticado. SABER, Revista Multidisciplinaria del Consejo de Investigación. Suplemento Vol. 17: 237-239

DA SILVA S, CASTRO EM, SOARES AM (2003) Effects of different water regimes on the anatomical characteristics of roots of grasses promising for revegetation of areas surrounding hydroelectric reservoirs. Ciénc Agrotec Lavras 27: 393-397
FACETTE MR, MCCULLY ME, CANNY MJ (1999) Response of maize roots to drying-limits of viability. Plant Cell Environ 22: 1559-1568

GARCÍA-NAVA R, PEÑA-VALDIVIA CB, RUÍZ PLM, TREJO LC (1999) Effect of synthetic ABA in root growth of domesticated and wild Phaseolus vulgaris L. Ann Rep Bean Improv Cooperative 42:85-86.

HOSE E, CLARKSON DT, STEUDLE E, SCHREIBER L, HARTUNG W (2001) The exodermis: a variable apoplastic barrier. J Exp Bot 52: 2245-2264

INTERGOVERNMENTAL PANEL ON CLIMATE CHANGE (2007a) Impacts, adaptation and vulnerability: contribution of working group II to the fourth assessment report of the IPCC. http//www.ipcc.ch.

INTERGOVERNMENTAL PANEL ON CLIMATE CHANGE (2007b) Climate Change Mitigation: contribution of working group III to the fourth assessment report of the IPCC. http://www.ipcc.ch/pdf/ assessment-report/ar4/wg3/ar4-wg3-frontmatter.pdf

LUX A, LUXOVA M, ABE J, MORITA S (2004) Root cortex: structural and functional variability and responses to environmental stress. Root Res 13: 117-131.

MA F, PETERSON CA (2003) Current insights into the development and chemistry of the endodermis and of roots. Can J Bot 81: 405-421.

NICOTRA AB, BABICKA N, WESTOBY N (2002) Seedling root anatomy and morphology: an examination of ecological differentiation with rainfall using phylogenetically independent contrasts. Oecologia 130:136-145

NORTH BG, PETERSON CA (2005) Water flow in roots: structural and regulatory features. In: Vascular Transport in Plants, eds. N.M. Holbrook and M.A. Zwieniecki. Publ. Elsevier Academic Press, New York. pp. 131-156.

PEÑA-VALDIVIA CB, GARCÍA NR, AGUIRRE RJR, TREJO LC (2002) High temperature breaks dormancy and increases hypocotyl-root growth of wild common bean (Phaseolus vulgaris L.). Seed Sc Tech 30: 231-248.

PEÑA-VALDIVIA CB, SÁNCHEZ-URDANETA AB, TREJO C, AGUIRRE RJR, CÁRDENAS E (2005) Root anatomy of drought sensitive and tolerant maize (Zea mays L.) seedlings under different water potentials. Cereal Res Comm 33: 705-712.

PEÑA-VALDIVIA CB, SÁNCHEZ-URDANETA AB (2009) Effects of substrate water potential in root growth of Agave salmiana Otto ex Salm-Dyck seedlings. Biol Res 42: 239-248

SALEEM M, LAMKEMEYER T, SCHÜTZENMEISTER, MADLUNG J, SAKAI H, PIEPHO HP, NORDHEIM A, HOCHHOLDINGE F (2010) Specification of cortical parenchyma and stele of maize primary roots by asymmetric levels of auxin, cytokinin, and cytokinin-regulated proteins. Plant Physiol 152: 4-18.

SÁNCHEZ-URDANETA AB, PEÑA-VALDIVIA CB, TREJO C, AGUIRRE RJR, CÁRDENAS SE, GALÍCIA JA (2003) Permeabilidad de las membranas radicales de plántulas de frijol (Phaseolus vulgaris L.) silvestre y domesticado bajo déficit de humedad. Interciencia 28: 597-603. 
SÁNCHEZ-URDANETA AB, PEÑA-VALDIVIA CB, AGUIRRE RJR, TREJO LC, CÁRDENAS-SORIANO E, GALÍCIA JAB (2004a) Crecimiento de la raíz de plántulas de frijol (Phaseolus vulgaris L.) silvestre y domesticado con déficit de humedad. Acta Científica Potosina 16: 18-42

SÁNCHEZ-URDANETA AB, PEÑA-VALDIVIA CB, AGUIRRE RJR, TREJO LC, CÁRDENAS-SORIANO E (2004b) Efectos del potencial de agua en el crecimiento radical de plántulas de Agave salmiana Otto Ex Salm-Dyck. Interciencia 29: 626-631.

SÁNCHEZ-URDANETA AB, PEÑA-VALDIVIA CB, TREJO LC, AGUIRRE RJR, CÁRDENAS SE (2005) Root growth and proline content in drought sensitive and tolerant maize (Zea mays L.) seedlings under different water potentials. Cereal Res Comm 33:697704.
SAS. 1999-2000. SAS user's guide: Statistics. Versión 8.1 Edition. SAS Institute Inc., Cary, NC. USA. $1290 \mathrm{p}$

SHAO H-B, CHU L-Y, JALEEL CA, ZHAO C-X (2008) Water-deficit stress-induced anatomical changes in higher plants. C R Biologies 33: 215-225

TERÁN, H.; SINGH, S.P. 2002. Comparison of sources and lines selected for drought resistance in common bean. Crop Sci. 42: 64-70

URREA CA, YONTS CD, LYON DJ, KOEHLER AE (2009) Selection for drought tolerance in dry bean derived from the Mesoamerican gene pool in western Nebraska. Crop Sci 49: 2005-2010.

WILCOX D, DOVE B, MCDAVID D, GREER D (2002) Image Tool for Windows. Version 3.0. The University of Texas Health Science Center. San Antonio, Texas. 
